\title{
The Influence of the Type of Surgical Thread and Suture in the Open Carpal Tunnel Syndrome Surgery
}

\section{A influência do tipo de fio cirúrgico e sutura nos resultados da cirurgia aberta da síndrome do túnel do carpo}

\author{
Marcelo José Silva Magalhães ${ }^{1,2}$ Beatriz Xavier Cruz ${ }^{3}$ Fabrício Conceição dos Santos ${ }^{3}$ \\ Isabella Mendes de Oliveira ${ }^{3}$ João Pedro Saraiva Sousa ${ }^{3}$ Thaís de Oliveira Guimarães ${ }^{3}$ \\ Thiago Antunes Lopes ${ }^{3}$ Ernesto José Hoffmann ${ }^{4}$
}

${ }^{1}$ Department of Neurosurgery, Hospital Vila da Serra, Belo Horizonte, MG, Brazil

2 Department of Medicine, Faculdades Unidas do Norte de Minas and Address for correspondence Marcelo José da Silva de Magalhães, MD, MSc, Rua Francisco Versiane Ataide, $n^{\circ} 760$, apartment $n^{\circ} 1301 .$, Montes Faculdades Itegradas Pitágoras, Montes Claros, MG, Brazil

3 Instituto de Ciências da Saúde, Faculdades Unidas do Norte de Minas, Montes Claros, MG, Brazil

${ }^{4}$ Department of Medicine, Instituto de Ciências da Saúde and Faculdades Integradas Pitágoras, Montes Claros, MG, Brazil

Arq Bras Neurocir 2019;38:292-296.

\begin{abstract}
Keywords

- carpal tunnel syndrome

- sutures

- suture techniques
\end{abstract}

\section{Resumo}

Carpal tunnel syndrome (CTS) is the result of compression and/or traction of the median nerve in the carpal tunnel. It is the most frequent compressive neuropathy of the upper limbs and it is usually idiopathic. Diagnosis is essentially clinical, defined by symptoms and provocative tests. Decompression of the median nerve by section of the transverse carpus ligament is the treatment of choice, but the lack of consensus on the type of suture and surgical thread to be used in the open carpal tunnel decompression surgery justifies the importance of evaluating the comparative results of existing studies, aiming to describe the influence of different types of sutures and surgical threads to guide the professionals about the most appropriate conduct. This is a systematic review of the international and national literature. Four studies comparing the influence of surgical threads and one study evaluating the influence of the type of suture were found. From the comparative studies, it was observed that there is advantage in the use of nonabsorbable suture due to the lower occurrence of inflammation and postoperative wound complications. When using Donatti sutures, wound edge inversion is less likely to occur compared with single individual sutures, but they are also related to longer postoperative pain.

A síndrome do túnel do carpo (STC) é resultante da compressão e/ou tração do nervo mediano no túnel do carpo. É a mais frequente neuropatia compressiva dos membros superiores e, geralmente, tem causa idiopática. O diagnóstico é essencialmente clínico através dos sintomas e testes provocativos. A descompressão do nervo mediano por secção do ligamento transverso do carpo é o tratamento de escolha, mas a ausência de consenso sobre o tipo de sutura e fio cirúrgico a serem utilizados na cirurgia aberta de received

January 9, 2017

accepted

April 12, 2017
DOI https://doi.org/

$10.1055 / \mathrm{s}-0037-1603106$. ISSN $0103-5355$.
Copyright $\odot 2019$ by Thieme Revinter

Publicações Ltda, Rio de Janeiro, Brazil
License terms

ㄷ) (i) $\ominus$ (\$) 
descompressão do túnel do carpo justifica a importância de se avaliar os resultados comparativos dos estudos existentes, tendo como objetivo descrever a influência dos diferentes tipos de suturas e fios cirúrgicos e, assim, orientar os profissionais quanto à conduta mais adequada. Trata-se de um estudo de revisão sistemática da literatura internacional e nacional. Foram encontrados quatro estudos comparando a influência dos tipos de fios cirúrgicos e um estudo avaliando a influência do tipo de sutura. A partir

Palavras-chave

- síndrome do túnel do carpo

- suturas

- técnicas de sutura dos estudos comparativos, observou-se que a utilização de sutura não absorvível se mostra vantajosa pela menor ocorrência de inflamação e complicações de ferida pósoperatória. Ao utilizar suturas Donatti, a inversão de bordas da ferida é menos provável de ocorrer em comparação com suturas individuais simples, porém estas estão relacionadas com dor pós-operatória mais prolongada.

\section{Introduction}

Carpal tunnel syndrome (CTS) is characterized by compression and/or traction of the median nerve at the level of the carpal tunnel, located in the fist. It is the most frequent compressive neuropathy of the upper limbs, with prevalence ranging from between $0.1251 \%$ to between 5 and $16 \%$, depending on the population group studied. ${ }^{1-3}$ Recent transversal studies evidenced a CTS prevalence of $9.2 \%$ in women and of $0.6 \%$ in men, with a peak incidence in the $6^{\text {th }}$ decade of life. ${ }^{1}$

The first description of CTS is attributed to Paget, in which a case of compression of the median nerve was described from a distal radius fracture. ${ }^{4}$ In 1913, the first anatomical and histopathological description of an hourglass lesion and median nerve neuroma was published, made by Marie et al. ${ }^{5}$ But it was only in 1950, in works conducted by Phalen, that the CTS principles were stablished. ${ }^{6}$

There is controversy among surgeons about the type of suture and surgical thread to be used in the closure of the skin in carpal tunnel decompression (CTD), considering the postoperative results. A consensus regarding the theme justifies the importance of evaluating study results that investigated the influence of suture and surgical thread types in postoperative evolution after CTD.

Several authors have compared the use of absorbable and nonabsorbable suture threads in carpal tunnel surgery, evaluating pain in the immediate and late postoperative period, patient satisfaction, as well as the incidence of complications, mainly infection and formation of granuloma. We have evaluated the results of these studies aiming to describe the influence of the different types of surgical sutures and thread on the evolution of the open surgery of carpal tunnel syndrome and, thus, guide professionals to the most appropriate approach.

\section{Methodology}

This is a systematic review of the international and national literature, in which systematic reviews and basic research studies were evaluated in an attempt to identify prognostic differences in the evolution of carpal tunnel syndrome surgery as to the type of surgical thread and suture used.
The search for data occurred between the months of October and November of 2016, through the public domain PubMed (National Library of Medicine [NLM]), Scientific Electronic Library Online (SciELO), Latin-American and Caribbean Literature in Health Sciences (LILACS), MEDLINE (NLM) and Virtual Health Library (BVSMS). The following health descriptors were used for the research: carpal tunnel syndrome, suture and suture techniques.

The inclusion criteria were: primary and flooded studies that addressed the influence of the different types of sutures and threads in the result of carpal tunnel syndrome open surgery, in the English and Portuguese languages. The exclusion criteria were: articles that did not refer to the influence of suture threads and suture type on the open surgical procedure of CTS.

The studies were analyzed and selected in two distinct phases: the first was based on searches guided by the inclusion and exclusion criteria, and the studies were selected or discarded based on their respective titles and abstracts. In the second phase, there was a complete trial of the studies, in which the type of research, the methods used, and the results were carefully analyzed to subsidize the development of the present systematic review.

All of the selected studies were distributed into five levels of evidence, according to the model proposed by the U.S. Preventive Services Task Force (USPSTF): (1) well-conducted randomized controlled clinical study; (2a) controlled clinical study without well-conducted randomization; (2b) a well-conducted cohort or case-control study; (2c) multiple longitudinal studies with or without intervention; and (3) opinions of respected authorities, based on clinical experience, descriptive studies and case reports, or reports from expert committees.

\section{Results}

Regarding the type of surgical thread, six comparative studies were found that met the inclusion criteria, being: (1) a prospective randomized study that used to Liou 64 patients comparing the use of an absorbable thread (polyglactin 910-Vicryl [Ethicon Inc., Sommerville, NJ, USA) in suture, and a nonabsorbable thread (polypropylene monofilament - Prolene [Ethicon Inc., Sommerville, NJ, USA]); (2) a prospective and randomized 
study that observed 47 patients undergoing suture closure with Vicryl Rapide (Ethicon Inc., Sommerville, NJ, USA) (absorbable) or Novafil (Medtronic, Dublin, Ireland) (nonabsorbable); (3) a randomized clinical trial comparing nylon, polyglactin 910 (Vicryl) or stainless steel in the closure of the skin in 61 patients; (4) A study evaluating 53 patients undergoing surgery for CTS with polypropylene (Prolene) or polyglactin (Vicryl Rapide) for skin closure; this study was also aimed at comparing the results of simple suture and subcutaneous suture; (5) a prospective randomized study that was performed to compare the influence of absorbable and nonabsorbable sutures on pillar pain, on scar sensitivity, on the extent of the wound inflammation, and on the overall result of open surgery of CTS in 33 patients; (6) the type of suture used was also evaluated in a prospective randomized controlled study with 89 patients, in which the results obtained between simple single suture and Donatti sutures were compared (-Table $\mathbf{1}$ ).

\section{Discussion}

The carpal tunnel is an inextensible and osteofibrous-aspect structure, delimited by the carpal bones and the flexor retinulus (FR), in which the nerve is present. ${ }^{7}$ Typically, the carpal tunnel also houses nine tendons of flexor muscles: the tendon of the flexor muscle along the thumb, four tendons of the superficial flexor muscles of the fingers, and four tendons of the deep flexor muscles of the fingers. ${ }^{5}$ The median nerve has motor and sensory branches. In the distal region of the carpal tunnel, the median nerve is divided into its terminal branches: (1) recurrent motor branch, which directs the thenar eminence, by the short abductor muscles of the thumb, opponent of the thumb and the superficial portion of the short flexor of the thumb; (2) branches for lumbrical muscles I and II; (3) sensory branches for the digital palmar nerves that, on the palmar surface, will innervate the skin of the thumb, the $2^{\text {nd }}$ and $3^{\text {rd }}$ fingers, besides the lateral half of the $4^{\text {th }}$ finger and, on the dorsal surface, the middle and distal phalanx of the $2^{\text {nd }}, 3^{\text {rd }}$ and half of the $4^{\text {th }}$ finger. ${ }^{7,8}$
Under the physiopathological aspect, CTS shares the same mechanism of other neuropathic syndromes that combine compression and tension phenomenon to provoke sensitive and or motor functional alterations. Such functional changes are, sequentially, due to intraneural blood microcirculation disturbances injuries in the myelin and axon sheath and, lastly, alterations in the supportive connective tissue. The compression of the median nerve can occur in two anatomically distinct sites, the first being at the proximal limit of the carpal tunnel, and the second at the level of the narrower portion of the tunnel, near the hamulus of the hamate bone. ${ }^{7,9}$

In the vast majority of cases, CTS is said to be idiopathic, since the actual cause of the condition cannot be identified. Secondary frames may be related to anomalies of the carpal tunnel walls (anomalies of the continent), or abnormalities that modify structures passing through the carpal tunnel (anomalies of the content). Authors also describe that occupational association pathologies are frequent in dynamic CTS. ${ }^{7}$

Carpal tunnel syndrome is evidenced by a clinical picture of pain, burning, tingling and numbness in the territory innervated by the median nerve, of insidious evolution and progressive character. Characteristically, the symptoms accentuate in the night period, even awakening the patient, and they tend to improve with hand movement. In more than half of the cases, the involvement is bilateral. With the progression of the disease, it can be associated with the reduction of sensitivity in the distribution of the median nerve and with a decrease in strength, and, when there is severe compression of the nerve, atrophy of the thenar eminence, usually related to short abductor thumb muscle atrophy. ${ }^{7,10}$ In the physical examination, hypoesthesia is observed in the median nerve territory, as well as thenar muscles paresis, positive Tinel, Phalen and Paley and McMurphy signals. ${ }^{7}$ The Paley and McMurphy signal and the Phalen signal show greater specificity, and the Tinel signal is the most sensitive. ${ }^{7,11}$

Table 1 General characteristics of the main studies evaluating the outcomes of carpal tunnel surgery according to the type of surgical wire and type of suture used

\begin{tabular}{|c|c|c|c|}
\hline Authors & $\begin{array}{l}\text { Number of } \\
\text { patients }\end{array}$ & Study type & Study objective \\
\hline Erel et $\mathrm{al}^{20}$ & 64 & $\begin{array}{l}\text { Randomized } \\
\text { prospective }\end{array}$ & $\begin{array}{l}\text { Evaluated the use or absorbable thread (polyglactin 910-Vicryl) } \\
\text { and nonabsorbable thread (polypropylene monofilament - Prolene) } \\
\text { in subcutaneous suture. }\end{array}$ \\
\hline Kharwadkar et al ${ }^{21}$ & 33 & $\begin{array}{l}\text { Randomized } \\
\text { prospective }\end{array}$ & $\begin{array}{l}\text { Compared the influence of absorbable and nonabsorbable thread } \\
\text { on pillar pain, scar sensibility, wound inflammation extension. }\end{array}$ \\
\hline Theopold et al ${ }^{22}$ & 47 & $\begin{array}{l}\text { Randomized } \\
\text { prospective }\end{array}$ & $\begin{array}{l}\text { Compared the use of suture com Vicryl Rapide (absorbable) } \\
\text { or Novafil (nonabsorbable). }\end{array}$ \\
\hline Menovsky et al ${ }^{23}$ & 61 & $\begin{array}{l}\text { Randomized } \\
\text { clinical trial }\end{array}$ & $\begin{array}{l}\text { Compared the use nylon thread, polyglactin } 910 \text { (Vicryl) } \\
\text { or stainless steel in skin suture. }\end{array}$ \\
\hline Macfarlane et $\mathrm{al}^{24}$ & 53 & $\begin{array}{l}\text { Randomized } \\
\text { clinical trial }\end{array}$ & $\begin{array}{l}\text { Compared the use of polypropylene (Prolene) and polyglactin } \\
\text { (Vicryl Rapide) threads for skin suture. }\end{array}$ \\
\hline Bolster et $\mathrm{al}^{25}$ & 89 & $\begin{array}{l}\text { Randomized } \\
\text { prospective }\end{array}$ & $\begin{array}{l}\text { Compared the results between simple individual } \\
\text { sutures and Donatti sutures. }\end{array}$ \\
\hline
\end{tabular}


The diagnosis of CTS is primarily clinical and can be firmed based on patient history and clinical examination. The use of complementary exams, such as electroneuromyography (ENMG) and imaging exams (ultrasonography and magnetic resonance imaging [MRI]), assists mainly in the differential and etiological diagnosis. ${ }^{7}$

Carpal tunnel syndrome treatment can be accomplished through two distinct approaches: conservative treatment and surgical treatment. ${ }^{12}$

Evidence suggests that conservative treatment may assist in the recovery of CTS patients with intra-articular injection of corticosteroids associated with lidocaine, as well as oral corticosteroid therapy and nocturnal immobilization, as effective therapies. Other therapeutical means, such as weight loss, ultrasound, laser, diuretics and vitaminotherapy B6, still remain controversial, not being recommended. ${ }^{12-14}$

In surgical treatment, the retinaculum section of the flexor muscles is done to increase the volume of the carpal tunnel and, consequently, reduce the intratunnel pressure. ${ }^{12}$ The decompression of the median nerve by section of the transverse ligament of the carpus is the treatment of choice, providing excellent results in $75 \%$ of the patients. ${ }^{15,16}$

Currently, three techniques are used to perform decompression of the carpal tunnel, which are: the open technique; the techniques known as mini-open; and endoscopic techniques. ${ }^{12}$

The endoscopic technique of CTD has become popular in recent years, allowing an early functional recovery of the hand, with low morbidity and faster return to habitual activities. ${ }^{14}$ The open surgery is characterized by a small incision of between 3 and $4 \mathrm{~cm}$, made between the flexion fold of the wrist, in the prolongation of the radial edge of the fourth finger, to the Kaplan Cardinal line. ${ }^{12}$ The FR is then incised in its middle part on the ulnar side of the shaft on the $4^{\text {th }}$ finger, leaving an ulnar margin to limit the subluxation of the flexor. The FR section remains cautiously distal to the superficial palmar arch and the median-ulnar anastomosis. Proximally, the FR is deeply separated from the synovia of the flexors with dissection shears. The closure of the skin is then done. ${ }^{12}$

The use of absorbable sutures is more and more frequent in hand surgery, since they do not require removal. Absorbable sutures have been associated with immunogenic response during the postoperative period, which can lead to complications such as residual inflammation of the wound, suture abscesses, and formation of sterile granuloma. This inflammatory response is a local reaction to the foreign body, with infiltration of macrophages that respond to proinflammatory cytokines, and the subsequent formation of Gigan cells. ${ }^{17}$ However, nonabsorbable sutures require postoperative removal, and some cases may also leave marks on the skin. ${ }^{18,19}$

Erel et al evaluated 64 patients in a prospective randomized clinical trial comparing the use of an absorbable thread (polyglactin 910-Vicryl) in subcutaneous suture with that of a nonabsorbable thread (polypropylene monofilament Prolene) in simple suture for surgical wound closure. An increase in pain perception in 10 days postoperatively was reported by patients in the group in which nonabsorbable polypropylene (Prolene) thread was used. In the evaluation after 6 weeks, there were differences in terms of cure, complications and pain score, with a higher level of residual inflammation in the group in which absorbable polyglactin 910 (Vicryl) thread was used. ${ }^{20}$

A prospective randomized study was performed to compare the influence of absorbable and nonabsorbable sutures on pillar pain, on scar sensitivity, on the extension of the wound inflammation and on the overall result of CTS open surgery in 33 patients. There was no significant difference between the two groups for any of the measures resulting from the final follow-up. ${ }^{21}$

In a prospective randomized study, Theopold et $\mathrm{al}^{22}$ observed 47 patients undergoing suture closure with Vicryl Rapide (absorbable) or Novafil (nonabsorbable). There were no differences in the appearance of the wound, pain or satisfaction at 2 or 6 weeks postoperatively. This study recommends using Vicryl Rapide to close the palmar incisions, in view of the convenience and cost savings associated with absorbable sutures. ${ }^{20}$

In a larger study, Menovsky et al performed a randomized clinical trial comparing nylon, polyglactin 910 or stainless steel in the closure of the skin in 61 patients undergoing open surgery for the treatment of CTS. Based on this study, absorbable sutures using polyglactin 910 should not be performed, since the incidence of complications, including infections and presence of suture granulomas, was much higher than in the nylon and steel suture groups. $^{23}$

Macfarlane et al analyzed 53 patients who underwent surgery for CTS with polypropylene (Prolene) or polyglactin (Vicryl Rapide) for skin closure. They did not observe any difference in the complications using the two types of suture, which can reflect the use of Vicryl Rapide, faster dissolution with a lower incidence of suture granulomas. It is important to note that this study analyzed the use of Prolene and Vicryl Rapide, which had not yet been directly compared by other authors when used in carpal tunnel surgery, finding little difference between the two products, with positive results, similar in both groups, regarding functionality, wound healing, and aesthetics. ${ }^{24}$

As for the type of suture, the use of simple sutures allows the nodes to be placed on the surface of the skin, far from the section point of the flexor rectangle, without the risk of delayed absorption under the skin, which is sometimes seen with the placement of a subcutaneous node in a continuous suture technique. ${ }^{24}$

Inversion of wound edges is one of the potential causes of fragility in the postoperative scar after CTS open surgery. When using Donatti sutures, the inversion of wound edges is less likely to occur in comparison with simple individual sutures. A prospective randomized side study was performed comparing simple single suture and Donatti sutures with 89 patients. After 8 weeks postoperatively, scar formation was good/very good in 94\% (individual points) and 97\% (Donatti) of the patients. Pain and disability scores in both groups improved after 8 weeks postoperatively, although patients who received Donatti sutures had a twofold higher score in pain scales. ${ }^{25}$ 


\section{Conclusion}

From the comparative studies, it was observed that the use of absorbable sutures is associated with an immunogenic response during the postoperative period, which can lead to complications such as residual inflammation of the wound, abscesses and formation of granulomas, justifying the use of nonabsorbable sutures. Thus, the studies infer that the use of absorbable thread presents results inferior to those observed when using nonabsorbable thread.

According to the data obtained, the use of nonabsorbable suture with polypropylene monofilament (Prolene) proved to be advantageous due to the lower occurrence of inflammation and postoperative wound complications.

If an absorbable suture thread is chosen, it is preferable to use Vicryl Rapide, since it has faster dissolution, decreasing the occurrence of inflammatory processes, with results similar to nonabsorbable threads.

As for the type of suture, both the Donatti suture and simple sutures presented excellent scar formation, but Donatti sutures are related to more prolonged postoperative pain. The simple suture obtained better results due to its more superficial location, with lower risk of delayed absorption under the skin, often observed in subcutaneous continuous suture.

\section{Conflicts of Interests}

The have no conflicts of interests to declare.

\section{References}

1 Atroshi I, Gummesson C, Johnsson R, Ornstein E, Ranstam J, Rosén I. Prevalence of carpal tunnel syndrome in a general population. JAMA 1999;282(02):153-158

2 Prick JJ, Blaauw G, Vredeveld JW, Oosterloo SJ. Results of carpal tunnel release. Eur J Neurol 2003;10(06):733-736

3 Tanaka S, Wild DK, Seligman PJ, Behrens V, Cameron L, PutzAnderson V. The US prevalence of self-reported carpal tunnel syndrome: 1988 National Health Interview Survey data. Am J Public Health 1994;84(11):1846-1848

4 Paget J. The first description of carpal tunnel syndrome. J Hand Surg Eur Vol 2007;32(02):195-197

5 Marie P, Foix C. Atrophie isolée de l'éminence thénar d'origine névritique. Rôle du ligament annulaire du carpe dans la pathogénie de la lésion. Rev Neurol (Paris) 1913;26:647-649

6 Phalen GS. The carpal-tunnel syndrome. Seventeen years' experience in diagnosis and treatment of six hundred fifty-four hands. J Bone Joint Surg Am 1966;48(02):211-228

7 Chammas M, Boretto J, Burmann LM, Ramos RM, Dos Santos Neto FÇ, Silva JB. Carpal tunnel syndrome - Part I (anatomy, physiology, etiology and diagnosis). Rev Bras Ortop 2014;49(05):429-436
8 Magalhães MJS, Ferreira VM. Síndrome compressiva de múltiplos nervos na dermatopolimiosite: relato de caso. Arq Bras Neurocir 2016;35(01):85-88

9 Doyle JR, Botte MJ. Surgical anatomy of the hand and upper extremity. Philadelphia: Lippincott, Williams \& Wilkins; 2003

10 Magalhães MJS, Correia AAÇ, Cruz EAS, et al. Síndrome do duplo impacto do nervo mediano: uma revisão de literatura. Arq Bras Neurocir 2017;36(01):1-74

11 Katz JN, Stirrat CR. A self-administered hand diagram for the diagnosis of carpal tunnel syndrome. J Hand Surg Am 1990;15 (02):360-363

12 Chammas M, Boretto J, Burmann LM, Ramos RM, Neto FS, Silva JB. Carpal tunnel syndrome - Part II (treatment). Rev Bras Ortop 2014;49(05):437-445

13 O'Connor D, Marshall S, Massy-Westropp N. Non-surgical treatment (other than steroid injection) for carpal tunnel syndrome. Cochrane Database Syst Rev 2003;1(01):CD003219

14 Piazzini DB, Aprile I, Ferrara PE, et al. A systematic review of conservative treatment of carpal tunnel syndrome. Clin Rehabil 2007;21(04):299-314

15 Bland JD. Treatment of carpal tunnel syndrome. Muscle Nerve 2007;36(02):167-171

16 Kim PT, Lee HJ, Kim TG, Jeon IH. Current approaches for carpal tunnel syndrome. Clin Orthop Surg 2014;6(03):253-257

17 Niessen FB, Spauwen PHM, Kon M. The role of suture material in hypertrophic scar formation: Monocryl vs. Vicryl-rapide. Ann Plast Surg 1997;39(03):254-260

18 Anderson JM, Rodriguez A, Chang DT. Foreign body reaction to biomaterials. Semin Immunol 2008;20(02):86-100

19 Postlethwait RW, Willigan DA, Ulin AW. Human tissue reaction to sutures. Ann Surg 1975;181(02):144-150

20 Erel E, Pleasance PI, Ahmed O, Hart NB. Absorbable versus nonabsorbable suture in carpal tunnel decompression. J Hand Surg [Br] 2001;26(02):157-158

21 Kharwadkar N, Naique S, Molitor PJA. Prospective randomized trial comparing absorbable and non-absorbable sutures in open carpal tunnel release. J Hand Surg [Br] 2005;30(01):92-95

22 Theopold C, Potter S, Dempsey M, O'Shaughnessy M. A randomised controlled trial of absorbable versus non-absorbable sutures for skin closure after open carpal tunnel release. J Hand Surg Eur Vol 2012;37(04):350-353

23 Menovsky T, Bartels RHMA, van Lindert EL, Grotenhuis JA. Skin closure in carpal tunnel surgery: a prospective comparative study between nylon, polyglactin 910 and stainless steel sutures. Hand Surg 2004;9(01):35-38

24 MacFarlane RJ, Donnelly TD, Khan Y, Morapudi S, Waseem M, Fischer J. Clinical outcome and wound healing following carpal tunnel decompression: a comparison of two common suture materials. BioMed Res Int 2014;2014:270137. Doi: 10.1155/2014/ 270137

25 Bolster M, Schipper C, Van Sterkenburg S, Ruettermann M, Reijnen $M$. Single interrupted sutures compared with Donati sutures after open carpal tunnel release: a prospective randomised trial. J Plast Surg Hand Surg 2013;47(04):289-291 